Thorax (1972), 27, 188.

\title{
Injuries of the trachea and bronchi
}

\author{
S. BERTELSEN and P. HOWITZ \\ Department of Surgery D, Rigshospitalet, and the University Institute of Forensic Medicine, \\ Copenhagen, Denmark
}

Traumatic rupture of the trachea or the bronchi is reported with increasing frequency. Such rupture may follow penetrating wounds, but the common cause is blunt trauma of the throat or thorax.

When the proximal trachea is damaged other cervical structures are usually involved. By contrast the distal trachea or bronchi are not infrequently the only thoracic structures damaged. In particular there may be no rib fractures, or obvious fractures may be uncomplicated and insignificant.

Thoracic rupture usually occurs in the vicinity of the carina.

Central rupture generally presents with emphysema of the mediastinum and neck. Diagnosis can usually be confirmed by tracheobronchoscopy. Rupture of the peripheral bronchi generally presents with pneumothorax and atelectasis.

Central rupture should be treated by primary suture. Lobectomy is often necessary when small bronchi are ruptured.

For some years now, reports of tracheal lesions and lesions of the large bronchi have become increasingly frequent. Increased incidence of thoracic trauma, associated with ever increasing traffic congestion and higher speeds, largely explains this, but a better understanding of possible complications of such trauma has also led to more frequent diagnosis (Peters, Loring, and Sprunt, 1958; Hood \& Sloan, 1959; Shaw, Paulson and Kee, 1961; Carter, Wareham, and Brewer, 1962; Harrington, Beall, and DeBakey, 1962; Logan, Abbott, and Hatcher, 1965; Beall, Noon and Harris, 1967).

Rapid diagnosis and primary treatment are essential, because tracheal and bronchial lesions are potentially rapidly fatal.

The possibility of bronchial rupture following thoracic injury has been recognized for many years. Seuvre (1873) reported one of the first cases, and for many years ruptures of the distal trachea and of the main bronchi were thought necessarily to entail $100 \%$ mortality. However, Krinitzki (1927) described rupture of the right main bronchus and total atelectasis of the right lung, found at necropsy in a 30-year-old woman, the aftermath of injuries some 20 years earlier. This was the first indication that such injuries need not be fatal.

In 1931, Nissen described main bronchus injury, subsequently complicated by stricture formation and purulent bronchiectasis, which was successfully treated by pneumonectomy. The first primary suture of a bronchial lesion was performed by Sanger (1945), and the first suture of a total rupture by Griffith (1949). The first suture of a total rupture of the trachea was performed by Beskin (1957). During the last 20 years there have been regularo reports of treatment of tracheal and bronchial lesions by primary suture. There have been rela? tively few reports from Scandinavia (Norlin, 1955 Wulff, Malm, Svanberg, and Wenckert, 1959: Sørensen, 1960; Thorén, 1962).

\section{MECHANISMS OF INJURY AND PATHOLOGY}

In general, there is good bony protection of the trachea and bronchial tree, but the cervical traches is exposed anteriorly and laterally. Lesions at this. site, however, are not common. This is probablôs because the lower jaw affords some protection, and because the trachea itself is not a delicate structure and in elastic and mobile (Fogelman and Steware 1956).

Lesions of the cervical trachea do occur followe ing sharp or blunt trauma to the anterior or latera aspects of the throat, or occasionally on hyperextension of the neck. Apart from bruising, trans verse or vertical lesions of the trachea may be seer Transverse lesions may be partial or total, an $\$$ vertical lesions may be confined to the membranous trachea. Both injuries, however, commonly involve rupture of the adjacent tracheal rings. 
Hyperextension of the head and neck stretches and compresses the trachea against the cervical spine. Transverse lesions between the second and sixth rings commonly result, and when there is total rupture, separation of the ends may be marked.

Injuries to the thoracic trachea and bronchi usually result from blunt thoracic trauma, but the precise mechanism is often obscure. When trauma is very severe the trachea and main bronchi may be crushed between the sternum and the spinal column, but generally it is supposed that the majority of injuries are indirect. Violent acceleration/deceleration of the relatively free lungs, or compression of the thorax in the sagittal plane, may rupture the stiff and relatively fixed tracheobronchial system.

The position of the vocal cords at the instant of accident may also be significant. Rupture may follow a rise in pressure when the glottis is closed. In support of this contention, such injuries to the tracheobronchial tree have been described after explosion of anaesthetic gases and following forced high-pressure ventilation. It is also possible that violent traumatic displacement of the diaphragm and abdominal organs can be significant. Perforations of the trachea and the main bronchi during instrumentation and long-term intubation have also been reported in recent years (Schönberg, 1912; Richards and Cohn, 1955; Peters et al., 1968; Hood and Sloan, 1959; Shaw et al., 1961; Carter et al., 1962; Larizadeh, 1966).

Transverse and/or vertical lesions of the lower respiratory tract may follow blunt thoracic trauma. Transverse lesions, partial or total, in the vicinity of the carina are the most common. Most commonly described, but not necessarily the most common in fact, is total rupture of the bronchus. Vertical lesions may occur at any site but are commonly seen in the trachea and larger bronchi posteriorly where the cartilage is deficient.

Penetrating wounds (knife or bullet) of the throat and chest wall may involve the respiratory tract together with other organs in the vicinity.

From the literature it appears that the majority of tracheal and bronchial injuries follow blunt trauma. Traffic accidents account for most of the intrathoracic lesions, but falls and crush injuries are also implicated. Although reports of respiratory tract damage increase, and the relationship with traffic accidents is clear, the total number is relatively small.

It is of considerable clinical interest, and a remarkable fact, that many patients with rupture of a bronchus have no other serious injury. There may be no demonstrable rib fracture in up to $50 \%$ of the patients (Griffith, 1949; Hood and Sloan, 1959; Larizadeh, 1966). On the other hand, traffic accident necropsies show that when thoracic trauma is severe, the tracheobronchial tree is frequently involved (McCarroll et al., 1962; Slätis, 1962; Sevitt, 1968).

\section{NECROPSY REPORT MATERIAL}

One thousand one hundred and seventy-eight necropsy reports on persons dying after trauma in the years 1961-66 were reviewed. In 33 instances there were lesions of the trachea and/or bronchi. Table I reviews the thoracic injuries and Table II gives the site of the tracheobronchial lesions.

There were 28 traffic accidents. In 22 cases, the individual (pedestrian, cyclist, motorcyclist) was struck by a car; the remaining six were probably steering column injuries. Two pedestrians were run over by a train, there were two instances of crush injuries at work, and one fall.

The relevant component of the accident was in 25 cases a violent blow on the chest, and in eight cases a crush injury. Three individuals had no demonstrable rib fractures, seven had fractures of between two and four ribs, and the remaining 23 had multiple rib fractures. Table III reviews the other injuries.

Death was virtually instantaneous in 27 cases: multiple fatal injuries were found in 24 persons, but in three the only serious injury was of the tracheobronchial tree. Six individuals were alive on arrival at hospital, five died between 45 minutes and two hours after admission. Of these five, four had multiple severe injuries, but in one the only serious finding

T A B L E I

THORACIC INJURIES-1178 NECROPSY STUDIES

\begin{tabular}{l|rr|rr}
\hline & Total & $\%$ & No Rib Fractures \\
\hline Rib fractures & 518 & 44 & & \\
Hamothorax & 379 & 32 & 20 & $5 \%$ \\
Lung lesions & 149 & 13 & 24 & $16 \%$ \\
Rupture of large vessels & 217 & 18 & 18 & $3 \%$ \\
Tracheobronchial rupture & 33 & $2 \cdot 8$ & 3 & \\
\hline
\end{tabular}

T A B L E II

SITE OF RUPTURE IN 33 INDIVIDUALS WITH RUPTURE OF THE TRACHEOBRONCHIAL TREE NECROPSY STUDY

\begin{tabular}{l|c|c}
\hline & No. & Site \\
\hline Trachea & 9 & $\begin{array}{c}4 \text { cervical } \\
5 \text { thoracic }\end{array}$ \\
Bronchi & 28 & $\begin{array}{c}23 \text { unilateral } 14 \text { right } \\
5 \text { bilateral }\end{array}$ \\
\hline Total & $37-4$ left \\
\hline
\end{tabular}


T A B L E I I I

DETAILED FINDINGS AT NECROPSY ON 33 INDIVIDUALS WITH RUPTURE OF THE TRACHEOBRONCHIAL TREE

\begin{tabular}{l|l|r}
\hline & & No. \\
\hline Rib fractures & Multiple & 23 \\
& Few (2-4 ribs) & 7 \\
\hline \begin{tabular}{l|r} 
Rupture of heart \\
or great vessels
\end{tabular} & Heart & 9 \\
& Aorta & 12 \\
& Pulmonary artery & 7 \\
& Coronary arteries & 2 \\
Vena cava & 2 \\
Laceration of lungs & Arch vessels & 2 \\
\hline Abdominal lesions & & 3 \\
& Ruptured aorta \\
& Ruptured renal artery & 1 \\
& Laceration of inf. vena cava & 1 \\
Ruptured spleen & 6 \\
CNS lesions & Ruptured liver & 5 \\
\hline
\end{tabular}

was rupture of a bronchus. The remaining patient had a left-sided haemothorax, and thoracotomy was performed. No bleeding site could be found and no injury to the lower respiratory tract was seen. The patient died 24 hours later in shock and respiratory insufficiency. At necropsy the only serious injury was rupture of a main bronchus.

In summary, 5 of the 33 individuals had isolated damage of the tracheobronchial tree. Of these five, one had total rupture of the distal trachea, three had unilateral total rupture of a main bronchus, and one had total rupture of one main bronchus and a partial transverse rupture of the other main bronchus. All had large quantities of blood in the lungs.

\section{CLINICAL MATERIAL}

Between the years 1955 and 1969, 11 patients with tracheobronchial lesions were treated in surgical department $\mathrm{D}$, the Rigshospital, Copenhagen. In seven cases the lesions followed blunt trauma (Table IV), and in three cases penetration (Table $V$ ). In one case a bronchus was perforated during endotracheal suction (Table V).

Traffic accidents accounted for four of the seven cases of blunt trauma, while the other three were crush injuries sustained at work.

The clinical findings in the 11 patients are shown in Table VI.

\section{Clinical PRESENTATION}

SYMPTOMS AND SIGNS When the trachea is partially ruptured, the main signs are mediastinal and neck emphysema. If the puncture is small, emphysema may not be very obvious and may develop slowly. With larger lesions emphysema usually develops rapidly and is extensive. Depen- dent on the degree of bleeding there may be cough, productive of varying quantities of blood-stained $\overline{0}$ mucus, and severe pulmonary distress may develop $\frac{\bar{\omega}}{\sigma}$ rapidly following aspiration of blood. Generally a $\mathbb{\varnothing}$ productive cough is significant of the larger lesions, while small lesions produce a dry irritative cough. क

When there is total rupture of the trachea, the $O$ ends are often widely separated. There is rapid $\overrightarrow{\vec{\omega}}$ onset of dyspnoea, cyanosis, and shock. Em- . physema may be extensive, if the patient survives $\overrightarrow{\vec{x}}$ for any length of time, but generally death is rapid. N

When there is rupture of the main bronchus, mediastinal and neck emphysema dominates the clinical picture. There is often pneumothorax. $\infty$ Bleeding may be evidenced by haemoptysis, and $\mathrm{O}$ dyspnoea and cyanosis follow aspiration.

Rupture of lobar and more peripheral bronchi $\bar{z}$ commonly presents with pneumothorax and mediastinal emphysema. Respiratory distress following $\stackrel{\rho}{工}$ aspiration of blood is also common.

DIAGNOSIS When it is appreciated how such lesions occur, and the clinical presentation is known, diagnosis is not difficult. It should be considered in all patients with thoracic trauma, especially when there is emphysema or pneumothorax. Particularly indicative clinical symptoms are:

(a) mediastinal, neck, and anterior thoracic wall emphysema;

(b) pneumothorax, especially when the lung does? not expand, when adequate drains are inserted, or when the quantity or air drained is large;

(c) total atelectasis of one lung or one lobe, which does not respond to treatment.

Ruptures of the trachea or larger bronchi may be seen on tracheoscopy and bronchoscopy with 을 greater or lesser ease, depending on the size of the $D$ rupture. Any bleeding points are suspicious of 0 perforation. If some time has elapsed since the accident there may be granulation tissue at the o site of the lesion. When there is rupture of peri- $N$ pheral bronchi, a diagnosis must be made from the clinical symptoms. A possible differential diagnosis is rupture of the lung tissue itself.

Bronchography may demonstrate lesions at all sites, but generally the condition of the patient con- $\stackrel{5}{-}$ traindicates this examination as an acute procedure. 0 Later such examination may be of value in demon- 0 strating bronchial stenosis after healing of the lesion (Weisel and Jake, 1953; Norlin, 1955; $\mathbb{\mathbb { Q }}$ Mahaffey, Creech, Born and DeBakey, 1956; 음 Hood and Sloan, 1959; Wulff et al., 1959; AlNaaman and Al-Qassab, 1966; Al-Omeri, 1969). 
TREATMENT

Tracheal rupture A small lesion should be treated by tracheostomy, to control the further development of emphysema by relieving pressure rises in the airway. Large or total rupture should be repaired immediately and tracheostomy performed, if possible distal to the lesion. The tracheostomy tube can usually be removed after approximately two weeks.

Lesions following blunt trauma of the throat are best approached through a cervical incision anterior to the sternocleidomastoid muscle, while open lesions can generally be sutured through the wound. Thoracotomy or sternotomy is necessary when the intrathoracic trachea is ruptured.

Central bronchial lesion On diagnosis thoracotomy should immediately be performed and the lesion sutured. When there is total rupture an anastomosis should be made. The suture site should be covered with pleura or pericardial tissue.

T A B L E I V

CLINICAL FINDINGS AND TREATMENT OF 7 PATIENTS WITH TRACHEOBRONCHIAL RUPTURE FOLLOWING BLUNT

\begin{tabular}{|c|c|c|c|c|c|c|c|c|c|}
\hline & \multirow[t]{2}{*}{$\begin{array}{l}\text { Sex } \\
\text { Age }\end{array}$} & \multirow[t]{2}{*}{$\begin{array}{l}\text { Cause of } \\
\text { Trauma }\end{array}$} & \multirow[t]{2}{*}{ Site of Injury } & \multicolumn{2}{|c|}{$\begin{array}{l}\text { Transverse } \\
\text { Rupture }\end{array}$} & \multirow[t]{2}{*}{$\begin{array}{l}\text { Lengthwise } \\
\text { Rupture }\end{array}$} & \multirow{2}{*}{$\begin{array}{l}\text { Other } \\
\text { Serious } \\
\text { Injury }\end{array}$} & \multirow[t]{2}{*}{ Treatment } & \multirow[t]{2}{*}{ Outcome } \\
\hline & & & & Total & Partial & & & & \\
\hline 1 & $\begin{array}{l}M \\
45\end{array}$ & $\begin{array}{l}\text { Traffic } \\
\text { accident }\end{array}$ & $\begin{array}{l}\text { Cervical trachea } \\
\text { (between 4-5 ring) }\end{array}$ & & + & & Oesophagus & $\begin{array}{l}\text { Primary suture } \\
\text { tracheostomy }\end{array}$ & $\begin{array}{l}\text { Died 4th postoperative } \\
\text { day, acute mediastinitis }\end{array}$ \\
\hline 2 & $\begin{array}{l}M \\
26\end{array}$ & $\begin{array}{l}\text { Accident } \\
\text { at work }\end{array}$ & $\begin{array}{l}\text { Cervical trachea } \\
\text { (between 5-6 ring) }\end{array}$ & & + & & Oesophagus & $\begin{array}{l}\text { Primary suture } \\
\text { tracheostomy }\end{array}$ & $\begin{array}{l}\text { Uncomplicated } \\
\text { recovery }\end{array}$ \\
\hline 3 & $\begin{array}{l}\mathbf{M} \\
\mathbf{2 1}\end{array}$ & $\begin{array}{l}\text { Accident } \\
\text { at work }\end{array}$ & $\begin{array}{l}\text { Right main bronchus } \\
\text { adjacent to carina }\end{array}$ & & + & & - & $\begin{array}{l}\text { Primary suture } \\
\text { tracheostomy }\end{array}$ & $\begin{array}{l}\text { Uncomplicated } \\
\text { recovery; mild } \\
\text { stenosis; no symptoms }\end{array}$ \\
\hline 4 & $\begin{array}{l}\mathbf{M} \\
17\end{array}$ & $\begin{array}{l}\text { Accident } \\
\text { at work }\end{array}$ & $\begin{array}{l}\text { Right }+ \text { left main } \\
\text { bronchi adjacent } \\
\text { to carina }\end{array}$ & $\stackrel{+}{+}$ & & $\begin{array}{l}+(\text { left }) \\
10 \mathrm{~mm}- \\
\text { membrane }\end{array}$ & 一 & $\begin{array}{l}\text { Primary suture } \\
\text { tracheostomy }\end{array}$ & $\begin{array}{l}\text { Uncomplicated } \\
\text { recovery; right main } \\
\text { bronchus stenosis; } \\
\text { no symptoms }\end{array}$ \\
\hline 5 & $\begin{array}{l}M \\
16\end{array}$ & $\begin{array}{l}\text { Traffic } \\
\text { accident }\end{array}$ & $\begin{array}{l}\text { Left main bronchus } \\
\text { adjacent to carina }\end{array}$ & & + & & $\begin{array}{l}\text { Contusion of } \\
\text { left lower } \\
\text { lobe }\end{array}$ & $\begin{array}{l}\text { Primary suture } \\
\text { tracheostomy; } \\
\text { lobectomy }\end{array}$ & $\begin{array}{l}\text { Uncomplicated } \\
\text { recovery }\end{array}$ \\
\hline 6 & $\begin{array}{l}\mathrm{M} \\
14 \\
\end{array}$ & $\begin{array}{l}\text { Traffic } \\
\text { accident }\end{array}$ & $\begin{array}{l}\text { Middle lobe } \\
\text { bronchus at origin }\end{array}$ & & & $\begin{array}{l}12 \mathrm{~mm}- \\
\text { membrane }\end{array}$ & $\begin{array}{l}\text { Cerebral } \\
\text { damage }\end{array}$ & Lobectomy & $\begin{array}{l}\text { Died 3rd postoperative } \\
\text { day, cerebral damage }\end{array}$ \\
\hline 7 & $\begin{array}{l}M \\
15\end{array}$ & $\begin{array}{l}\text { Traffic } \\
\text { accident }\end{array}$ & $\begin{array}{l}\text { Cervical trachea } \\
\text { (between 1-3 ring) }\end{array}$ & & & $\begin{array}{l}10-12 \mathrm{~mm}- \\
\text { junction of } \\
\text { cartilage and } \\
\text { membrane }\end{array}$ & $\begin{array}{l}\text { Right lung } \\
\text { contusions } \\
\text { pneumothorax }\end{array}$ & $\begin{array}{l}\text { Right pleural } \\
\text { drain }\end{array}$ & $\begin{array}{l}\text { Uncomplicated } \\
\text { recovery }\end{array}$ \\
\hline
\end{tabular}

T A B L E V

CLINICAL FINDINGS AND TREATMENT OF 4 PATIENTS WITH TRACHEOBRONCHIAL RUPTURE FOLLOWING PENETRATING WOUNDS

\begin{tabular}{|c|c|c|c|c|c|c|c|c|c|}
\hline \multirow[t]{2}{*}{ No. } & \multirow[t]{2}{*}{$\begin{array}{l}\text { Sex } \\
\text { Age }\end{array}$} & \multirow[t]{2}{*}{$\begin{array}{l}\text { Cause of } \\
\text { Trauma }\end{array}$} & \multirow[t]{2}{*}{ Site of Injury } & \multicolumn{2}{|c|}{$\begin{array}{c}\text { Transverse } \\
\text { Rupture }\end{array}$} & \multirow[t]{2}{*}{$\begin{array}{c}\text { Lengthwise } \\
\text { Rupture }\end{array}$} & \multirow{2}{*}{$\begin{array}{l}\text { Other } \\
\text { Serious } \\
\text { Injury }\end{array}$} & \multirow[t]{2}{*}{ Treatment } & \multirow[t]{2}{*}{ Outcome } \\
\hline & & & & Total & Partial & & & & \\
\hline 8 & $\begin{array}{c}F \\
35\end{array}$ & $\begin{array}{l}\text { Attempted } \\
\text { suicide }\end{array}$ & $\begin{array}{l}\text { Cervical trachea } \\
\text { (between 3-4 ring) }\end{array}$ & & + & & Oesophagus & $\begin{array}{l}\text { Primary suture } \\
\text { tracheostomy }\end{array}$ & $\begin{array}{l}\text { Uncomplicated } \\
\text { recovery }\end{array}$ \\
\hline 9 & $\underset{35}{M}$ & $\begin{array}{l}\text { Attempted } \\
\text { suicide }\end{array}$ & $\begin{array}{l}\text { Cervical trachea } \\
\text { (between 2-3 ring) }\end{array}$ & & + & & - & $\begin{array}{l}\text { Primary suture } \\
\text { tracheostomy }\end{array}$ & $\begin{array}{l}\text { Uncomplicated } \\
\text { recovery }\end{array}$ \\
\hline 10 & $\begin{array}{l}M \\
14\end{array}$ & $\begin{array}{l}\text { Shot } \\
\text { wound }\end{array}$ & $\begin{array}{l}\text { Left main bronchus } \\
\text { adjacent to carina } \\
\text { (tangential tear) }\end{array}$ & & + & & $\begin{array}{l}\text { Small puncture } \\
\text { of pulmon- } \\
\text { ary artery; } \\
\text { haemoperi- } \\
\text { cardium }\end{array}$ & $\begin{array}{l}\text { Primary suture } \\
\text { tracheostomy }\end{array}$ & $\begin{array}{l}\text { Uncomplicated } \\
\text { recovery }\end{array}$ \\
\hline 11 & $\begin{array}{l}\mathbf{M} \\
71\end{array}$ & $\begin{array}{l}\text { Endo- } \\
\text { tracheal } \\
\text { suction }\end{array}$ & $\begin{array}{l}\text { Right main bronchus } \\
\text { adjacent to carina } \\
\text { (perforation) }\end{array}$ & & + & & - & - & $\begin{array}{l}\text { Died 4th postoperative } \\
\text { day, acute mediastinitis }\end{array}$ \\
\hline
\end{tabular}


T A B LE V I

CLINICAL FINDINGS IN 11 PATIENTS WITH TRACHEOBRONCHIAL RUPTURE: CASE NUMBERS AS IN TABLES IV AND V

\begin{tabular}{|c|c|c|c|c|c|c|c|c|}
\hline \multirow{2}{*}{ No. } & \multicolumn{2}{|c|}{ Emphysema } & \multirow{2}{*}{ Dyspnoea } & \multirow{2}{*}{ Cyanosis } & \multirow{2}{*}{ Pneumothorax } & \multirow{2}{*}{ Atelectasis } & \multirow{2}{*}{ Haemoptysis } & \multirow[t]{2}{*}{ Rib Fracture } \\
\hline & Mediastinum & Neck & & & & & & \\
\hline $\begin{array}{r}1 \\
2 \\
3 \\
4 \\
5 \\
6 \\
7 \\
8 \\
9 \\
10 \\
11\end{array}$ & $\begin{array}{l}+ \\
+ \\
+ \\
+ \\
\pm \\
- \\
+ \\
+ \\
+\end{array}$ & $\begin{array}{l}+ \\
+ \\
+ \\
+ \\
+ \\
+ \\
+ \\
+ \\
+ \\
+ \\
+\end{array}$ & $\begin{array}{l}+ \\
+ \\
+ \\
+ \\
+ \\
+ \\
+ \\
+ \\
+ \\
+\end{array}$ & $\begin{array}{l}+ \\
+ \\
+ \\
+ \\
- \\
- \\
+ \\
+\end{array}$ & $\begin{array}{c}+ \\
+ \\
+ \text { (later) } \\
- \\
+ \\
+\end{array}$ & $\begin{array}{l}- \\
\overline{+} \\
+ \\
+ \\
\pm \\
- \\
= \\
- \\
+ \\
-\end{array}$ & $\begin{array}{l}+ \\
+ \\
+ \\
+ \\
+ \\
+ \\
+ \\
+ \\
+ \\
+\end{array}$ & $\begin{array}{l}- \\
- \\
- \\
+ \\
+ \\
- \\
- \\
- \\
- \\
-\end{array}$ \\
\hline
\end{tabular}

Tracheostomy should be performed, and maintained for approximately two weeks.

Peripheral bronchial lesion Treatment in this instance can be more conservative. Pneumothorax is treated by drainage, but if there is no response to this treatment thoracotomy and lobectomy may be necessary.

Prophylactic antibiotic cover is recommended over a period of 10 to 14 days in all cases to reduce the risk of mediastinitis and pneumonia.

\section{BLUNT TRAUMA}

TRACHEAL RUPTURE Two patients had incomplete transverse rupture of the cervical trachea. Both patients had been violently struck on the lateral side of the throat, and, apart from the tracheal rupture, there were crushed tracheal rings and crush-lesions of the cervical part of the oesophagus in both cases. The ruptures were sutured in both cases and distal tracheostomy was performed. One patient died with acute descending purulent mediastinitis on the fourth day.

A further patient had a rupture of the membranous cervical trachea following blunt lateral trauma of the throat. The rupture was $10-12 \mathrm{~mm}$ long and localized at the junction of the cartilage and membrane. The patient also had left-sided recurrent nerve paresis and fractures of ribs 3 to 6 on the right side with contusion of the lung and pneumothorax. The results of conservative treatment were good.

RUPTURE OF MAIN BRONCHUS There were three instances of such lesions, two following crush injuries, and one a steering column injury. Two patients had unilateral partial transverse rupture, while the other had a total rupture of the right main bronchus and a lengthwise rupture of the left main bronchus at the junction of the cartilage 오 and membrane.

One of these patients had three fractured ribs, 3 and a contusion of the left lower lobe, which $\frac{0}{3}$ required treatment. The other two patients had no additional serious injuries, and specifically no rib fractures.

The ruptures were sutured and covered with pleura or pericardial tissue. All patients underwent tracheostomy.

RUPTURE OF PERIPHERAL BRONCHUS One patient $\frac{\mathscr{Q}}{\varnothing}$ had a lengthwise rupture of the middle lobe $\stackrel{\varrho}{\Rightarrow}$ bronchus, beginning at its origin, and contusions $\overrightarrow{0}$ and lacerations of the lobe. Three ribs on the right side were fractured, and the patient also had cerebral contusions. Middle lobectomy was performed. The patient died on the third day following operation as a result of the cerebral damage.

\section{PENETRATING WOUNDS}

TRACHEAL RUPTURE Two patients had a partial transverse rupture of the trachea following suicide attempts. One-half to three-quarters of the circumference of the trachea was involved in both cases. One of the patients also had a lesion of the oesophagus. Suture and tracheostomy were performed $\mathcal{N}$ in both cases.

BRONCHIAL RUPTURE One patient had a tangential lesion of the left main bronchus close to the carinar following an accidental shot wound of the thorax.? The pulmonary artery was involved, and there was haemopericardium. The bronchial lesion was sutured and covered with pericardial tissue.
A further patient had a rupture of the mem- $\frac{}{\Phi}$ branous part of the right main bronchus close to $\frac{\Omega}{8}$ the carina following endotracheal suction. Theo patient died on the fourth day following the injury from acute mediastinitis. 
All patients were given intensive antibiotic cover during the first 10 to 12 days after injury.

As recorded, there were three primary deaths, two from acute purulent mediastinitis and one from cerebral damage.

The other patients had uncomplicated recoveries. All are now without symptoms, and tracheobronchoscopy and bronchography performed at followup have shown healed tracheal lesions without stenosis, while there is insignificant stenosis of the main bronchi at the site of sutures. The patient with lesions of both the trachea and oesophagus following attempted suicide had some narrowing of the oesophagus.

\section{DISCUSSION}

The clinical series presented here gives some idea of the possible forms of injury to the tracheobronchial system, and also illustrates some of the mechanisms of such injury. The series supports the contention that rupture of the tracheobronchial tree following blunt thoracic trauma generally occurs around the carina, that is to say, the distal trachea or the main bronchi at the origin.

The actual mechanism of tracheobronchial injury following blunt trauma is not clear. Generally, a number of factors are probably involved, but one alone may be responsible in certain circumstances.

Our study of necropsy reports supports the conclusion of earlier studies that traffic accidents are the most common cause of tracheobronchial lesions, and that such injuries are frequently combined with other potentially fatal injuries. On the other hand, it is apparent from virtually all studies that, on occasion, tracheobronchial damage may be the only serious injury (Gammelgaard et al., 1956; McCarroll et al., 1962; Slätis, 1962; Sevitt, 1968).

In the necropsy series reviewed here there were five such cases, and it seems apparent that a vital factor in the mortality was aspiration of blood into otherwise normal lungs.

In the clinical series, two patients with bronchial rupture following blunt trauma had other fatal lesions. Only two patients had demonstrable rib fractures and these were not serious. By contrast, both blunt and sharp trauma, which damages the cervical trachea, generally involves other structures in the throat.

Small tracheal ruptures generally heal without complication. If large or total rupture of the trachea is overlooked when acute tracheostomy distal to the rupture is performed for respiratory distress, severe tracheal stenosis will follow. Such patients are usually severely incapacitated and present difficult technical surgical problems. Often permanent tracheostomy is the only answer. If a patient survives the acute phase of an undiagnosed rupture of a bronchus, the outcome depends on the nature of that rupture. Stenosis and recurrent symptoms generally follow incomplete rupture, while the lung distal to a complete rupture will collapse, and, though there is risk of infection, patients may remain without pulmonary symptoms (Wulff et al., 1959).

Tracheobronchial rupture is not common, even among patients subjected to thoracic trauma, and very few such patients will be seen in the average thoracic surgery department.

Initial treatment of patients with lesions of the tracheobronchial tree does not differ in principle from treatment of other patients with thoracic damage. The five persons in the necropsy review, whose only pathology was a lesion of the trachea or a bronchus complicated by aspiration of blood into the airway, demonstrate clearly that correct initial treatment is essential. A free airway must be established and adequate ventilation ensured. It may also be necessary on occasion to insert a pleural drain, and if this initial treatment is begun, in most cases the critical phase will be controlled so that patients can be transferred to a specialist department.

\section{REFERENCES}

Al-Naaman, Y. D., and Al-Qassab, F. A. (1966). Successfully repaired traumatic avulsion of the right main stem bronchus. Int. Surg., 45, 272.

Al-Omeri, M. M: (1969). Traumatic rupture of left main stem bronchus. Arch. Surg., 99, 346.

Beall, A. C., Noon, G. P., and Harris, H. H. (1967). Surgical management of tracheal trauma. J. Trauma, 7, 248.

Beskin, C. A. (1957). Rupture-separation of the cervical trachea following a closed chest injury.J. thorac. Surg., 34, 392.

Carter, R., Wareham, E. E., and Brewer, L. A. (1962). Rupture of the bronchus following closed chest trauma. Amer. J. Surg., 104, 177.

Fogelman, M. J., and Stewart, R. D. (1956). Penetrating wounds of the neck. Amer. J. Surg., 91, 581.

Gammelgaard, P. A., Gormsen, H., Halkier, E., Jessen, C., and Therkelsen, F. (1956). Traffic deaths in Denmark during 1955. Acta Med. leg. soc., 9, 47.

Griffith, J. Lloyd (1949). Fracture of the bronchus. Thorax, 4, 105.

Harrington, O. B., Beall, A. C., and DeBakey, M. E. (1962). Traumatic injuries to the cervical trachea. Amer. J. Surg., 103, 541.

Hood, R. M., and Sloan, H. E. (1959). Injuries of the trachea and major bronchi. J. thorac. cardiovasc. Surg., 38, 458.

Krinitzki, S. I. (1927). Zur Kasuistik einer vollständigen Zerreissung des rechten Luftröhrenastes. Virchows Arch. path. Anat., 266, 815. 
Larizadeh, R. (1966). Rupture of the bronchus. Thorax, 21, 28.

Logan, W. D., Abbott, O. A., and Hatcher, C. R. (1965). Acute tracheal trauma. Amer. Surgn, 31, 600.

Mahaffey, D. E., Creech, O., Boren, H. G., and DeBakey, M. E. (1956). Traumatic rupture of the left-main bronchus successfully repaired eleven years after injury. J. thorac. Surg., 32, 312.

McCarroll, J. R., Braunstein, P. W., Cooper, W., Helpern, M., Seremetis, M., Wade, P. A., and Weinberg, S. B. (1962). Fatal pedestrian automotive accidents. J. Amer. med. Ass., 180, 127.

Nissen, R. (1931). Exstirpation eines ganzen Lungenflügels. Zbl. Chir., 58, 3003.

Norlin, U. A. T. (1955). Traumatic rupture of the main bronchi. Acta radiol. (Stockh.), 43, 305.

Peters, R. M., Loring, W. E., and Sprunt, W. H. (1958). Traumatic rupture of the bronchus. Ann. Surg., 148, 871.

Richards, V., and Cohn, R. B. (1955). Rupture of the thoracic trachea and major bronchi following closed injury to the chest. Amer. J. Surg., 90, 253.
Sanger, P. W. (1945). Evacuation hospital experiences with war wounds and injuries of the chest. Ann. Surg., 122, 147.

Schönberg, S. (1912). Bronchialrupturen bei Thoraxkompression. Berl. klin. Wschr., 49, 2218.

Seuvre, M. (1873). Écrasement par une roue d'omnibus. Rupture de la bronche droite. Bull. Soc. anat. Paris, (48e année), 5e sér, 8, 680.

Sevitt, S. (1968). Fatal road accidents. Brit. J. Surg., 55, 481.

Shaw, R. R., Paulson, D. L., and Kee, J. L. (1961). Traumatic $\vec{\omega}$ tracheal rupture. J. thorac cardiovasc. Surg., 42, 281.

Slätis, P. (1962). Injuries in fatal traffic accidents. Acta chir. $\vec{x}$ scand., Suppl., 297, 9.

Sørensen, H. R. (1960). Traumatic rupture of the main bronchus. Acta chir. scand., 119, 346. Thorén, L. (1962). Complete traumatic rupture of the $\vec{\infty}$
bronchus. Acta chir. scand., 124, 365.

Weisel, W., and Jake, R. J. (1953). Anastomosis of right 윽 bronchus to trachea forty-six days following complete bronchial rupture from external injury. Ann. Surg., 137, 220.

Wulff, H. B., Malm, A., Svanberg, L., and Wenckert, A. (1959). Traumatic bronchial rupture. Acta chir. scand., Suppl., 245, 142. 